\title{
INCOME-ELASTICITY OF POULTRY MEAT CONSUMPTION IN METROPOLITAN AREAS OF BRAZIL
}

\author{
Miriam Rumenos Piedade Bacchi ${ }^{1 *}$; Humberto Francisco Silva Spolador ${ }^{2}$ \\ ${ }^{1}$ Depto. de Economia, Administração e Sociologia - USP/ESALQ, C.P. 9 - CEP: 13418-970 - Piracicaba, SP. \\ ${ }^{2}$ Pós-Graduando em Economia Aplicada - USP/ESALQ \\ ${ }^{*}$ Corresponding author <mrpbacch@esalq.usp.br>
}

\begin{abstract}
Studies on the meat market behavior may result in interesting parameters for the market and public policy agents. The definition of the income-elasticity of poultry consumption enables the elaboration of prospective analysis on the potential demand of this product. Thus, the main objective of the present study is to estimate the income-elasticities of poultry consumption. Data from the 1995-96 and 1987-88 Consumer Expenditure Survey, published by IBGE (Brazilian Institute of Geography and Statistics), were used in the analysis. The elasticities were obtained by fitting a three-segment polygonal curve relating the logarithm of the per capita poultry meat consumption as a function of the per capita family income. Generalized Least Squares method was used for the econometric model fitting. The elasticities were obtained considering the total, carcasses and selected individual poultry parts consumption. Average income elasticity of the total consumption enables the classification of poultry meat as a normal product. The observed average income elasticities showed that breast and thighs are superior products. In the last period, a negative elasticity was observed for carcasses.
\end{abstract}

Key words: meat market, food consumption

\section{ELASTICIDADE-RENDA DO CONSUMO DE FRANGO NAS REGIÕES METROPOLITANAS DO BRASIL}

\begin{abstract}
RESUMO: Estudos sobre o comportamento de mercado de carnes podem gerar parâmetros de interesse para agentes do setor e formuladores de políticas. A definição da elasticidade renda do consumo de frango permite a elaboração de análises prospectivas sobre a demanda potencial desse produto. Dessa forma, 0 presente estudo teve por objetivo principal estimar as elasticidades-renda do consumo físico de carne de frango. Resultados da Pesquisa de Orçamento Familiares (POF) de 1987-88 e de 1995-96, publicados pelo IBGE (Instituto Brasileiro de Geografia e Estatística) foram utilizados na análise. As elasticidades foram obtidas por meio do ajustamento de uma poligonal com três segmentos relacionando o logaritmo do consumo físico per capta de carne de frango com o recebimento familiar per capta. Para o ajustamento do modelo foi utilizado o método de Mínimos Quadrados Generalizados. As elasticidades foram obtidas considerando o consumo total, o de carcaça e o de alguns corte individuais de frango. O resultado referente à elasticidaderenda média para consumo total permite classificar o frango como um bem normal. As elasticidades-renda médias obtidas apontam que o peito de frango e a coxa são bens superiores. No que se refere à carcaça (frango abatido na designação do IBGE), foi observado, para o último período, elasticidade-renda média negativa.
\end{abstract}

Palavras-chave: mercado de carnes, consumo de alimentos

\section{INTRODUCTION}

Brazilian poultry production has increased considerably over the last decades. Its share in world's production raised from $2.2 \%$ in 1974 to $14 \%$ in 1999 . In this period, Brazil went up from tenth to second in the ranking of the largest world producers, below United States only. In relation to exports, Brazil also stands out as the third largest world exporter, after the United States and Hong Kong (ABEF - Brazilian Association of Poultry Producers and Exporters).

Poultry is nowadays one of the main sources of protein for the Brazilian consumer. In 1999, according to ABEF, the annual per capita consumption of poultry was $29 \mathrm{~kg}$, which was comparable to beef consumption and exceeded by far the consumption of pork. Analyzing aspects related to the poultry-slaughtering sector in Brazil, Barros (1994) pointed out that the sector had an important role in the improvement of Brazilian food quality.

The significance of poultry slaughtering in the nation's economy and of the poultry meat in the Brazilian consumer's nutrition make the implementation of the analysis of the consumption of this item extremely important, especially because it can help agents of the sector in making decisions regarding production and commercialization. Knowing poultry demand elasticities allows a prospective analyses of its internal consumption to be made, enabling the identification of its exportable surplus. Besides this, these studies can underlie the formulation of sectoral policies. 
Therefore, the main objective of this study is to determine poultry demand income-elasticity. Given the increasing trend, in the last few years, of the consumption of specific parts of the carcass, elasticity for the most consumed parts - breast and thighs - were also analyzed.

\section{Analysis of the Poultry Market}

Over the last decades, Brazilian poultry slaughtering was the agricultural activity with the highest production and productivity levels. This activity has incorporated great technological advances and, today, its performance is comparable to that of developed countries such as the United States and France.

In 1970, Brazil produced approximately 200 thousand tons of poultry. By 1995, the production had increased to 4 million tons. The industry grew $1,760 \%$ in the period of 25 years with an average annual rate of $14.42 \%$ (Araujo, 1996). The evolution of Brazilian production in the last 10 years can be seen in Table 1, where we can verify that the variation rate is positive for every year of the series, reaching 19\% in 1995.

The increase in production and productivity of poultry slaughtering after the 1970 s caused a sharp decrease in the price of poultry in the 90s (Figure 1). By the end of the $90 \mathrm{~s}$, the price of poultry was more than $50 \%$ lower than the price at the end of the 80 s. However, since 1995, the price has decreased at lower rates than the observed in the early 90 s.

Considering the present technological level, a sharp decrease in the price of poultry would only be possible as a consequence of a fall in the price of the inputs used in its production. As effect of productivity increase and fall of prices, a great and constant increase in the consumption of this product has been observed (Figure 2).

The consumption of poultry, and more specifically the white meat, has also been stimulated by the search for a healthier low-fat diet as a result of the valorization of health- and aesthetic-related aspects. Besides this, the

Table 1 - Brazilian poultry production - 1989-1999. Source: Brazilian Association of Poultry Producers and Exporters - ABEF*.

\begin{tabular}{|c|c|c|}
\hline Year & Production & Variation \\
\hline & --------- t --------- & ------- \% -------- \\
\hline 1989 & $2,055.287$ & - \\
\hline 1990 & $2,267.358$ & 10.32 \\
\hline 1991 & $2,521.911$ & 11.23 \\
\hline 1992 & $2,726.992$ & 8.13 \\
\hline 1993 & $3,142.998$ & 15.26 \\
\hline 1994 & $3,411.026$ & 8.53 \\
\hline 1995 & $4,050.449$ & 18.75 \\
\hline 1996 & $4,051.561$ & 0.03 \\
\hline 1997 & $4,460.925$ & 10.10 \\
\hline 1998 & $4,498.186$ & 0.83 \\
\hline 1999 & $5,526.044$ & 13.40 \\
\hline
\end{tabular}

*www.abef.com.br

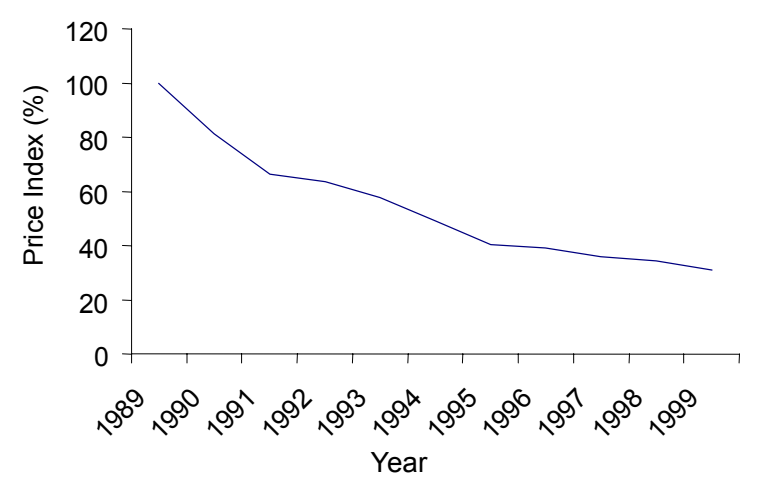

Figure 1 - Evolution of the annual average retail price indices for poultry, 1989-1999. Calculated by the authors with primary data from FIPE - Foundation Institute of Research in Economics.

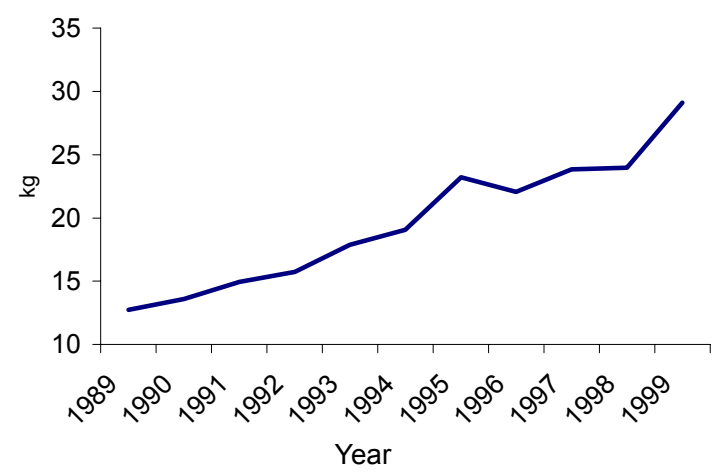

Figure 2 - Evolution of per capita poultry consumption - 1989-1999. Source: ABEF - Brazilian Association of Poultry Producers and Exporters (www.abef.com.br).

intense migration to urban areas in the 1970 s created a new potential market for poultry products (Rizzi, 1993). The consumption of poultry increased at an average rate of $8.1 \%$ per year between 1989 and 1999 .

An important fact for the poultry meat market in the last decade was the increase in the commercialization of special parts. In some metropolitan areas of Brazil, the current consumption of parts is relatively high. In 1995/ 96, the consumption of parts (breast, thighs, wings) in São Paulo, for example, represented approximately $30 \%$ of the consumption of eviscerated poultry and, in Curitiba, approximately $16 \%$ (IBGE).

Brazilian companies of the poultry sector have tried to meet consumer preferences in terms of weight, meat color and parts that are specific to each niche of the market. The technological evolution of the sector provided the necessary conditions for the use of less noble parts. For example, parts of the bone, ribs and neck are used in the manufacturing of sausages and cold cuts.

With the technological advances incorporated in Brazilian aviculture and the consequent fall in poultry production costs, the Brazilian product has now a larger share in the international market. The performance of Brazilian exports of whole poultry (carcass) and parts can be seen in Figure 3, which shows an expressive growth in the 90s. 


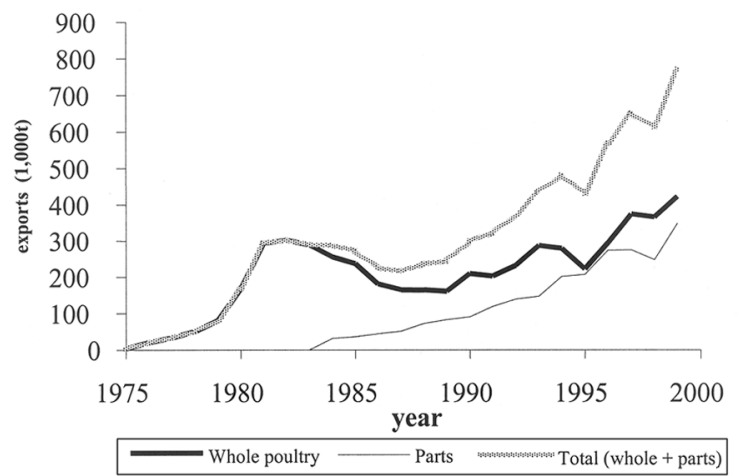

Figure 3 - Evolution of Brazilian Poultry Exports - whole poultry and parts - 1975/1999. Source: ABEF - Brazilian Association of Poultry Producers and Exporters (www.abef.com.br).

Distribution of family monthly income in the income classes of the Consumer Expenditure Survey

In order to estimate the income-elasticity of the physical consumption of poultry and poultry parts, data from the IBGE's Consumer Expenditure Survey for nine metropolitan areas (Belem, Fortaleza, Recife, Salvador, Belo Horizonte, Rio de Janeiro, São Paulo, Curitiba and Porto Alegre), the Federal District and the city of Goiania were used in this study. The data are presented for individual metropolitan areas and for "all areas". The latter is the object of this analysis.

IBGE distributes families into 10 classes according to their income ${ }^{1}$, (Table 2), which also presents the number of families per income class, the average number of people per family and the monthly per capita income for each class. The analysis used the surveys from 1987-88 and 1995-96, published in 1991 and 1998, respectively, with the objective of analyzing changes occurred in the period.

Per capita consumption of poultry - comparison of the data from the Family Income Surveys from 198788 and 1995-96

In Table 3, data of per capita consumption of poultry per income class is presented for "all areas", considering the carcass (slaughtered poultry according to IBGE) and parts for 1987-88 and 1995-96. Comparing 1995-96's to 1987-88's values, the consumption of noble parts (breast) by higher classes has increased significantly in the period studied. This increase in consumption is associated to aspects related to health and aesthetics. The consumption of thigh by higher-class families (three highest income classes) also increased between 1987-88 and 199596 , although less expressively than that of breast. The highest increase in the consumption of parts took place in families whose income ranged from 20 to 30 minimum salaries. We could not observe a defined pattern for the consumption of wings, and a decrease was verified in some income classes, whereas in others, consumption increased. Between 1987-88 and 1995-96, there was an increase in the consumption of carcass by lower income families. The increase was more expressive for families whose income was below eight minimum salaries. For lower classes, the consumption of poultry must be more associated to the fall in prices than to the "health effect". The consumption of carcass by higher-class families has fallen in the studied period.

\section{The method for elasticity determination}

The estimates of consumption income-elasticities for poultry and poultry parts were obtained by fitting a polygonal curve with two vertices (three segments), considering the model:

$\ln C_{i}=\beta_{0}+\beta_{1} \ln R_{i}+\sum_{h=1}^{2} \delta_{h} Z_{h i}$ (n $\left.R_{i}-\ln \phi_{h}\right)+\mu_{i}$

where $C_{i}$ is the per capita poultry consumption of the $i_{-}{ }^{\text {th }}$ class; $R_{i}$ is the per capita family income of the $i^{i-}$ class, $\phi_{h}$ is the family income level corresponding to the $h^{\text {th }}$ vertex (with $\phi_{1}<\phi_{2}$ ); $Z_{h i}$ is a binary variable, being $Z_{h i}=0$ if $R_{i}$ is less than or equal $\phi_{h}$ and $Z_{h i}=1$ if $R_{i}$ is more than $\phi_{h}$, and $\mu_{i}$ are independent errors with average zero and variance inversely proportional to the number of families per class of family income.

The three segments of the polygonal curve correspond to three strata with limits $\phi_{1}$ and $\phi_{2}$. The elasticity in strata I, in which $R \leq \phi_{1}$, equals $\beta_{1}$; the elasticity in strata II, in which $\phi_{1}<R \leq \phi_{2}$ equals $\beta_{1}+\delta_{1}$; and the elasticity in strata III, according to which $R \leq \phi_{2}$ equals $\beta_{1}+\delta_{1}+\delta_{2}$.

The limit between two strata of per capita income was taken as the limit between the two classes of family income divided by the geometrical average of the average size of the families in these two classes (Hoffmann, 2000).

The weighed least squares method was used to estimate the parameters of the model. The number of families per family income class was used as the weighing factor.

The calculation of the average elasticities of the strata was done through the weighed average of the elasticities of each stratum, and the weighing factor used was the participation of each stratum in the total consumed amount.

Several models were fitted considering alternative forms of grouping the income classes of the Consumers Expenditure Survey in the three strata.

\section{RESULTS AND DISCUSSION}

The poultry consumption income-elasticities obtained for the different strata and the average elasticity for the consumption of whole poultry, carcass, breast, and thigh are presented in Table 4.

\footnotetext{
${ }^{1}$ All economic revenues are considered income: wages, rental, sporadic sales of goods (estate or non-estate), loans, gains with investments, profits, income tax restitution, etc. (IBGE, 1999:30).
} 
Table 2 - Number of families, family average size, per capita income in the 10 family monthly income classes for the total of the areas covered by the Consumers Expenditure Survey - 1987-88 and 1995-96. Source: IBGE

\begin{tabular}{|c|c|c|c|c|c|c|}
\hline \multirow[t]{2}{*}{ Income classes } & \multicolumn{2}{|c|}{ Number of families } & \multicolumn{2}{|c|}{$\begin{array}{c}\text { Average number of } \\
\text { family members }\end{array}$} & \multicolumn{2}{|c|}{ Monthly per capita income per income class } \\
\hline & $\begin{array}{l}1987-88 \\
(1,000)\end{array}$ & $\begin{array}{l}1995-96 \\
(1,000)\end{array}$ & $1987-88$ & $1995-96$ & $\begin{array}{c}\text { 1987-88 (US\$ } \\
\text { Dec./1987 exch. rate) }\end{array}$ & $\begin{array}{c}1995-96 \text { (US\$ } \\
\text { Dec./1995 exch. rate) }\end{array}$ \\
\hline Up to 2 & 956 & 1,305 & 2.88 & 2.96 & 48.99 & 51.67 \\
\hline Over 2 to 3 & 813 & 1,050 & 3.50 & 3.37 & 97.85 & 86.27 \\
\hline Over 3 to 5 & 1,804 & 1,912 & 4.01 & 3.74 & 156.09 & 122.88 \\
\hline Over 5 to 6 & 777 & 892 & 4.20 & 3.75 & 214.78 & 169.79 \\
\hline Over 6 to 8 & 1,226 & 1,387 & 4.26 & 3.83 & 273.48 & 211.97 \\
\hline Over 8 to 10 & 908 & 972 & 4.28 & 3.95 & 350.46 & 265.82 \\
\hline Over 10 to 15 & 1,547 & 1,661 & 4.29 & 3.93 & 477.46 & 362.98 \\
\hline Over 15 to 20 & 902 & 964 & 4.33 & 3.96 & 677.72 & 513.39 \\
\hline Over 20 to 30 & 890 & 945 & 4.40 & 3.82 & 951.09 & 746.32 \\
\hline Over 30 & 1,192 & 1,456 & 4.29 & 3.71 & 2360.160 & 1865.09 \\
\hline
\end{tabular}

Note: In 1987-88, the minimum salary was US\$ 39.12 in the exchange rate of December, 1987 and in 1995/96, it corresponded to US\$115.67, considering to exchange rate of December, 1995.

Table 3 - Annual per capita consumption of poultry per household.

\begin{tabular}{|c|c|c|c|c|c|c|c|c|c|c|c|c|}
\hline \multirow[t]{2}{*}{$\begin{array}{l}\text { Income } \\
\text { classes }\end{array}$} & \multicolumn{5}{|c|}{$1987-88$} & \multicolumn{3}{|c|}{$1995-96$} & \multicolumn{4}{|c|}{ Ratio 1995-96/1987-88 } \\
\hline & Breast & Thigh & Wing & Carcass & Breast & Thigh & Wing & Carcass & Breast & Thigh & Wing & Carcass \\
\hline & & & & & & & kg ---- & & & & & \\
\hline Up to 2 & 0.21 & 0.13 & 0.19 & 8.22 & 0.21 & 0.16 & 0.13 & 13.29 & 1.01 & 1.25 & 0.71 & 1.62 \\
\hline Over 2 to 3 & 0.11 & 0.13 & 0.13 & 11.67 & 0.11 & 0.23 & 0.17 & 14.40 & 1.04 & 1.76 & 1.33 & 1.23 \\
\hline Over 3 to 5 & 0.13 & 0.27 & 0.25 & 9.79 & 0.29 & 0.45 & 0.19 & 14.19 & 2.20 & 1.71 & 0.76 & 1.45 \\
\hline Over 5 to 6 & 0.26 & 0.31 & 0.50 & 11.89 & 0.22 & 0.38 & 0.20 & 15.49 & 0.83 & 1.24 & 0.41 & 1.30 \\
\hline Over 6 to 8 & 0.48 & 0.39 & 0.30 & 11.61 & 0.77 & 0.89 & 0.37 & 14.69 & 1.60 & 2.28 & 1.25 & 1.27 \\
\hline Over 8 to 10 & 0.31 & 0.46 & 0.35 & 11.32 & 1.26 & 0.83 & 0.67 & 12.87 & 4.10 & 1.78 & 1.90 & 1.14 \\
\hline Over 10 to 15 & 0.50 & 0.79 & 0.27 & 12.23 & 1.28 & 0.62 & 0.27 & 14.21 & 2.56 & 0.78 & 1.01 & 1.16 \\
\hline Over 15 to 20 & 0.61 & 0.80 & 0.24 & 10.84 & 1.90 & 1.17 & 0.29 & 12.81 & 3.10 & 1.46 & 1.19 & 1.18 \\
\hline Over 20 to 30 & 1.12 & 0.77 & 0.22 & 11.20 & 4.91 & 3.12 & 0.63 & 13.65 & 4.39 & 4.04 & 2.93 & 1.22 \\
\hline Over 30 & 1.87 & 1.19 & 0.32 & 11.63 & 4.75 & 1.53 & 0.31 & 10.89 & 2.54 & 1.29 & 0.97 & 0.94 \\
\hline
\end{tabular}

Source: IBGE

Table 4 - Income-elasticities of the consumption of poultry and parts.

\begin{tabular}{|c|c|c|c|c|c|c|c|}
\hline \multirow[t]{2}{*}{ Product } & \multirow[t]{2}{*}{ Survey date } & \multirow[t]{2}{*}{$\begin{array}{l}\text { Grouping } \\
\text { schema }\end{array}$} & \multirow[t]{2}{*}{$\mathrm{R}^{2}$} & \multicolumn{3}{|c|}{ Strata elasticities } & \multirow[t]{2}{*}{$\begin{array}{c}\text { Average } \\
\text { elasticities }\end{array}$} \\
\hline & & & & I & $\|$ & III & \\
\hline \multirow{2}{*}{$\begin{array}{l}\text { Whole } \\
\text { chicken }\end{array}$} & $1987-88$ & $5-3-2$ & 0.98 & 0.16 & 0.14 & 0.16 & 0.16 \\
\hline & $1995-96$ & $7-2-1$ & 0.99 & 0.18 & 0.85 & -0.40 & 0.28 \\
\hline \multirow[t]{2}{*}{ Carcass } & $1987-88$ & $7-2-1$ & 0.87 & 1.50 & 0.33 & 0.25 & 1.10 \\
\hline & $1995-96$ & $5-3-2$ & 0.91 & 0.55 & -1.32 & -2.05 & -0.46 \\
\hline \multirow[t]{2}{*}{ Breast } & $1987-88$ & $7-2-1$ & 0.84 & 0.58 & 0.82 & 0.79 & 0.70 \\
\hline & $1995-96$ & $7-2-1$ & 0.98 & 0.59 & 6.30 & -1.58 & 2.41 \\
\hline \multirow[t]{2}{*}{ Thigh } & $1987-88$ & $5-3-2$ & 0.96 & 0.69 & 0.81 & 0.53 & 0.68 \\
\hline & $1995-96$ & $7-2-1$ & 0.91 & 0.77 & 2.10 & -1.57 & 1.04 \\
\hline
\end{tabular}

Source: Authors' elaboration

In order to calculate the per capita consumption of whole poultry the values of acquisition of the carcass (slaughtered poultry according to IBGE's designation), live poultry, parts and roasted poultry were added. In order to transform the values of acquisition of live poultry and roasted poultry into equivalent carcass, a conversion factor of 0.846 , for live poultry and 1.520 , for roasted poultry were used. The poultry consumed in parts was transformed into carcass considering the consumption of breast and its participation in the carcass $(0.274 \%)$. The breast was the chosen part because it represented the highest weight in the carcass as compared to the other consumed parts. The use of this system enables consumption to be taken in consideration in the definition of the total value. The coefficients used for the transformations were taken from the following publications: Griswold (1972) for roasted poultry, SENAC (1993) for breast, and Mead (1995) for live poultry. 
The values presented for the elasticities refer to the elasticities obtained through the best fitted model, that is, the model which had the highest determination coefficient among some models that considered alternatives of grouping the 10 family income classes.

The average income-elasticities obtained for 1995-96 are higher than those obtained for 1987-88, both in the case of total poultry consumption as in the case of specific parts of the carcass. This is probably due to a larger consumption of poultry by the Brazilian consumer in a scenario in which significant changes happened in the population's meat consumption habits.

When the elasticities obtained for the individual strata related to the 1987-88 survey are compared to the ones obtained for the respective strata related to the 1995-96 survey (although they do not include exactly the same income classes), in all analyzed cases there was a change in the sign of the last strata, showing that the carcass and the individual parts started being regarded as inferior goods by higher income classes.

In the case of the carcass, a great sign change occurred in the second stratum. In 1995-96, high incomeelasticities were found for special parts (thigh and breast) in the second stratum, which includes families whose income range from 15 to 30 minimum salaries.

The elasticity estimated for the first stratum, which includes the lowest income classes, for both special parts (breast and thigh) and total consumption, which also includes these parts, is lower than that obtained for the second stratum, which contradicts the empirical knowledge and the economic theory, which postulates elasticities as inversely proportional to income. This fact may be associated to the consumption habit, that is, the small share occupied by the special parts in the nutrition of these families. Thus, the consumption of parts from eviscerated poultry by lower income classes changes little due to income variations.

The carcass is taken as an inferior good by families from the second income stratum when the second period of the analysis is considered. This may show that the families in th is stratum may be willing to substitute the carcass by nobler parts of poultry or even by beef. Hoffman (2000) estimated positive elasticities of beef for families earning up to 30 minimum salaries. These high elasticities reflect the changes verified in the consumption habits of families from these income classes, who incorporated the special parts of poultry into their diet.

The inferences done by analyzing the average elasticities must be more precise than those made analyzing individual elasticities. This may occur because in the case of some strata, there are only one or two income classes, which can confer some degree of imprecision in the estimate of these individual elasticities.

The value found for the average income elasticity of the total physical consumption of poultry in this study is close to the one obtained for the income-elasticity of the expenditure in poultry by Hoffmann (2000). Incomeelasticities for special parts were not estimated by other Brazilian authors, so a comparison of results is difficult. In fact, this study is unique regarding both, the analysis of income elasticities related to the total consumption of poultry (using the Consumers Expenditure Survey's data addition) and the analysis of the income elasticities for the special parts.

Although the elasticities were obtained through data surveyed in metropolitan areas, since most of the population lives in urban areas, these values may represent well the relations between national income and consumption in general.

The low income-elasticity of the total consumption of poultry leads us to the conclusion that the consumption of this product will increase little due to variations of the national income. This suggests that, in a scenario of stable vegetative growth, one must search for a higher insertion in the international market so that production can grow at rates that are similar to those observed in recent years. This must take place in a context where a great price reduction should not be expected, what could lead to a significant increase in the internal consumption.

The average income elasticities obtained for noble parts indicate a significant increase in the consumption of these parts in face of an increase in income. On the other hand, the average income elasticity obtained for the consumption of carcass indicates a decrease in the consumption in face of an increase in income. In the event of an increase in income, there may be a change in the relative prices (of carcass and parts) and that there is a need for searching alternatives to improve the processing of eviscerated carcass in order to obtain higher efficiency in the production of industrialized products.

\section{REFERENCES}

ARAÚJO, M.P. Rentabilidade da produção de frango de corte sob contratos de integração vertical em Minas Gerais. Piracicaba, 1996. 133p. Dissertação (Mestrado) - Escola Superior de Agricultura "Luiz de Queiroz", Universidade de São Paulo.

BARROS, G.S. de C. Formação de preços no setor de corte no Brasil. Piracicaba. 1994. 88p. (Relatório de Pesquisa).

GRISWOLD, R.M. Estudo experimental de alimentos. São Paulo: Edgard Blücher, 1972. 469p.

HOFFMANN, R. Elasticidade-renda das despesas e do consumo físico de alimentos no Brasil Metropolitano em 1995-96. Agricultura em São Paulo, v.30, p.111-122, 2000.

FUNDAÇÃO INSTITUTO BRASILEIRO DE GEOGRAFIA E ESTATÍSTICA IBGE. Pesquisa de orçamentos familiares 1987-88. Rio de Janeiro: IBGE, 1991.

FUNDAÇÃO INSTITUTO BRASILEIRO DE GEOGRAFIA E ESTATÍSTICA IBGE. Pesquisa de orçamentos familiares 1995-96. Rio de Janeiro: IBGE, 1998.

MEAD, G.C. Processing of poultry. Londres: Chapman \& Hall, 1995. 423p. RIZZI, A.T. Mudanças tecnológicas e reestruturação da indústria agroalimentar: o caso da indústria de frangos no Brasil. Campinas, 1993. 201p. Tese (Doutorado) - Universidade Estadual de Campinas.

SERVIÇO NACIONAL DE APRENDIZAGEM COMERCIAL - SENAC Orientações sobre o comércio varejista de carne. São Paulo: Editora Senac. 1993. 121p.

Received September 21, 2001 